\title{
How to enhance the smoothness of university students' study paths?
}

Määttä, Kaarina

University of Lapland, Finland (Kaarina.Maatta@ulapland.fi)

Uusiautti, Satu

University of Lapland, Finland (satu@uusiautti.fi)

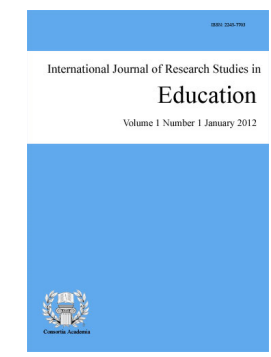

ISSN: $2243-7703$ Online ISSN: 2243-7711

\begin{abstract}
Today's educational policies aim at making education more effective. However, in order to realize this in practice, not only reforms in educational policy or institutions are enough. More attention should be exerted on students' study paths as a whole. Using the descriptive research design paradigm, this article shall present an illustration of the factors that comprises the university students' study paths. Based on the illustration, the authors discuss what good university studying is and how teachers are able to make students progress with their study paths smoother. The authors argue that teachers should be more thoughtful and willing to genuinely help and confront students as individuals. In essence, teachers should act as mentors who further students' engagement in studying.
\end{abstract}

Keywords: higher education; studying; student engagement; mentoring; university education 


\section{How to enhance the smoothness of university students' study paths?}

\section{Introduction}

\subsection{Challenging and Demanding Nature of University Studies}

Across the Organization for Economic Co-operation and Development (OECD) countries, governments are seeking policies to make education more effective while searching for additional resources to meet the increasing demand for education (OECD, 2010). It would be an ideal situation if the young chose their study fields; were aware of their own talents and points of interests, knew the options for education; were able to start in their favorite field right after graduating from high school, and set their dream jobs as their goals and where they could start working right after taking the degrees (Sundvall-Huhtinen, 2007). Yet, the reality does not appear like this. Many of the young do yet know after high school what their aspirations and goals for life are or what they are capable of doing. Some of them think they know but get disappointed: the field does not correspond to one's hopes or one's interests and values change along with getting more life experience. Some may persistently apply for the same education for years although the study place in question was not the only one or even the best option any longer.

Obviously, students aim at learning and quality study attainment. However, "Student survey 2010 University students' subsistence and studying" report (see Ministry of Education and Culture, 2010) revealed that a third of students think that their studies have proceeded more slowly than they had intended. Working had hindered the progress the most. Indeed, international comparisons support this finding: according to OECD Indicators (OECD, 2010), full-time students have a better change of graduating than part-time students. In the Finnish survey (Ministry of Education and Culture, 2010), a remarkable proportion of students (34\%) thought that their stress affected their studies. $30 \%$ of university students thought that they do not have sufficient funding for the time they study. While $75 \%$ are confident with their future and future employment.

Furthermore, studies (e.g. Schoon et al., 2010; Ministry of Education and Culture, 2010) prove that moving slowly from one educational level to another and prolonged studies predict dissatisfaction later on in life. Slow transition and late graduation postpone starting a family and employment. In addition, prolonged studies add fatigue and especially the feelings of cynicism and insufficiency which, for their part, lowers down zest for studying and predicts depression later on. Smooth studies and study success reflect in students' wellbeing as a life-long project. Graduation is important otherwise too: according to San Antonio (2008), those holding a four-year college degree now earn, on average, 2.5 times as much as those without a high school diploma. Thus, fast graduation is not only - or should not only be -the university's goal to save societal resources as it would obviously be beneficial for students as well - at least financially.

In order to be able to make students' study paths smoother, it seems important to analyze what factors affect their careers as students. In this article, we will introduce a characterization of a student's study path and its core factors. After introducing the overall model about what factors affect students' prompt and smooth progress, we will discuss what good university studying and learning is and finally, how a university teacher as a mentor can enhance and support students' successful and engaged progress in university education.

\subsection{The Starting Point: Finnish University Students in Statistics}

According to a report compiled by Finnish Ministry of Education and Culture (2010), about $75 \%$ of graduates apply for higher education immediately after graduation from high school. However, only less than $40 \%$ of them manage to get in at once: $21 \%$ starts studies at universities and $18 \%$ at universities of applied sciences (equal to polytechnic or vocational high school). The young tend to apply over and over again for that 
particular educational field they find the most appealing and therefore, the commencement of their studies becomes prolonged. In Finland, the median of the age when students go to higher education is 21.4 years which is the fourth highest in OECD countries. A fifth of new students are over 26 years old. Most of the new students have graduated in the prior years from high school or they already have one academic degree or permission to study at some other university. After one year since graduation from high school, over half and after three years $70 \%$ of the graduates have gotten in a university or university of applied sciences. The corresponding number, for example, in USA is $64 \%$ (OECD, 2010).

In Finland, 43\% of the age 20-29 people are in education which is the highest in OECD countries where the mean is $25 \%$. On the other hand, more men from 20-24 years old are outside education and unemployed than in OECD countries on average (OECD, 2010). This number partly tells about the delay in moving from secondary education to higher education as well as about the difficulties of finding a job after taking a degree in secondary education. It is also noted that the average study time at universities and universities of applied sciences is around 4.9 years in Finland, while in OECD countries it is 4.1 years. Especially, university students' study paths are long. About $30 \%$ of university students in OECD countries do not finish their studies; the corresponding figure in Finland is 28\% (Ministry of Education and Culture, 2010; OECD, 2010). Each year there are over 8,000 university student drop-outs in Finland; this is actually around six percent of the total student population. Among the students of universities of applied sciences, the corresponding number is around 12,000 which make about ten percent of the student population (Ministry of Education and Culture, 2010).

In essence, there are almost as many reasons for dropping out as there are drop-outs (see also Kuh et al., 2008). Their study field may be wrong, student counseling may be insufficient, a change in personal life may take place, a crisis makes studying impossible, or working life appears more attractive. Some drop-outs return studying afterwards, some never will. Many dream of finishing their studies and they do not even feel like having made a wrong choice although work may have taken them in another direction.

\subsection{Research Questions}

In order to enhance students' progress and to avoid dropping out and delays in graduation, the authors will take a closer look at university students' study process. With an objective of answering the following question:

1. What factors students' study paths are comprised of

2. What good university studying and learning is?

3. How university teachers can support successful and engaged studying?

\section{Background of a Successful Study Path}

In a number of studies, student engagement has been identified as a desirable trait in schools; however, there is little consensus among students and educators as to how to define it. Usually, it refers to students' willingness to participate in routine school activities, such as attending class, submitting required work, and following teachers' directions in class. According to Kuh et al. (2008, p. 542), "student engagement represents both the time and energy students invest in educationally purposeful activities and the effort institutions devote to using effective educational practices". However, the term is also increasingly used to describe meaningful student involvement throughout the learning environment, including students participating curriculum design, classroom management and school building climate. Furthermore, it can be used to refer to student involvement in extra-curricular activities in the campus life of a university which are thought to have educational benefits (Fletcher, 2005; Pintrich, 1999). Kuh (2003) has developed a framework for student engagement based on fife benchmarks: level of academic challenge, enriching educational experiences, supportive campus environment, student-faculty interaction, and active and collaborative learning. Therefore, it seems that engagement is one basic concept when considering successful studying. 
Yet, the student is the core factor in that path through whom all the other factors can be dissected. Everyone's goal for succeeding in studies is not the same but students may have different motives that direct their studying. Someone may only aim at taking a degree while the other wants to achieve top-expertise in the field, improve the quality of life or desire to reach some personally important, long-term goal (Locke, 2002). Thus, everyone also perceives success in studies subjectively and evaluates personal achievements in different ways (Maddux, 2002). Expectations for the future affect greatly how people react on changes and challenges (Carver \& Scheier, 2002) and there are various strategies that lie behind the one that leads to active and meaningful studying.

For example, Locke (2002, p. 303) has illustrated action that leads to the achievement of goals which can be adopted in the dissection of a study path as well. In order to be able to achieve the goals one has set for studies, one has to direct action soundly in relation to the goal. Succeeding requires constant trying. One has to contemplate what one wants to achieve and why, what kinds of goals one should set, how to reach these goals, how to prioritize the demands that are at variance with the goal, and how to handle forthcoming obstacles and setbacks - how to achieve the goal one dreams about. When it comes to studying, the strategy could start from finding a study place and field that is the most suitable, proceeding determinedly by acquiring profound knowledge and skills from the field and finally graduating in reasonable time (Locke, 2002).

Baltes and Freund (2006) have introduced the Selection-Optimization-Compensation (SOC) model which grounds on the thought that there are three fundamental processes that direct development during people's life span: selection, optimization, and compensation. A combination of these would form an efficient and multipurpose mechanism through which individuals, groups, and societies could achieve at higher levels of operation and control future challenges (Baltes \& Freund, 2006). Selection means developing, cultivating, and engaging in the goals and it directs one's development by concentrating one's resources on certain fields and directing one's behavior in various situations and moments. Selection can be either selective or reactive. When it comes to university students, selection means engaging in studying and, for example selecting those courses and study units that fit the best to one's skills and strengths. Optimizing refers to a process where one acquires, develops, coordinates and applies appropriate means or resources in relation to the goal (e.g. choosing such studying methods that one finds the most suitable) whereas compensation means employing optional or new means in order to maintain certain levels of activities when the old means fall down (Baltes \& Freund, 2006). Students should be ready to try alternative methods in order to perform well - all tasks cannot be completed in the same manner but one has to be prepared to re-assess situations and one's choices and skills all the time.

Covey (2004), on the other hand, suggests that a path to success or toward a desired goal is a combination of knowledge, skills, and will. Knowledge answers the question what to do and why. Skills provide the answer for how to do it. Will can be understood as a synonym for motivation or need to do something or achieve something (see also Deci, Vallerand, Pelletier, \& Ryan, 1991). When these three dimensions converge, such a strategy is born through which some goal will be achieved. Yet, besides students' choices and attitudes, also institutional factors can enhance the experience of meaningful studying. Therefore, when defining a student's meaningful study path, it is important to pay attention to the holistic nature of the study process. It means that the study process progresses as an entity within the functional interaction in person-environment system. Furthermore, positive development depends on the fact how well the inner and outer functions are synchronized. Inner processes are, for example, mental, biological, and behavioral functions while the opportunities provided by the environment, expectations, and rules are outer processes (Magnusson \& Mahoney, 2006).

Cruce, Wolniak, Seifer, and Pascarella (2006) suggest that good practices in education have a unique, positive impact on student development although they vary by the students' background characteristics and pre-college development as well as by the institution attended. Still, these practices affect, for example, student engagement which can be seen as one main pillar in successful and meaningful study path. Kezar and Kinzie (2006) have introduced features of a quality undergraduate education which has been associated with student engagement: quality begins with an organizational culture that values high expectations, respect for diverse 
How to enhance the smoothness of university students' study path?

learning styles, and emphasis on the early years of study; quality undergraduate curriculum requires coherence in learning, synthesizing experiences, on-going practice of learned skills, and integrating education with experience; and quality undergraduate instruction builds in active learning, assessment and prompt feedback, collaboration, adequate time on task, and out of class contact with faculty (see also Kuh, 2003).

Universities aim at securing good and quality learning. According to the present ideas (Leppilampi \& Piekkari, 2001), good and efficient learning is constructivist (personal and active understanding and the construction of skills and meanings as well as information seeking and processing), cumulative (learning is always based on previously learned information and skills), self-directed (involves meta-cognitive processes or a student's ability to plan, control, and assess his/her own action), goal-oriented (understanding about the goals of learning and their meaning), situation-bound (learning can be improved by connecting it to its real environment, live situation in its real context), and cooperative (students' mutual talking has proven especially important for learning).

Zhao and Kuh (2004) recognize the constructivist view behind student engagement and generation of information by emphasizing the meaning of constructing and assimilating knowledge through a reciprocal process with the teacher and peers. Theilheimer (1991) presents a detailed list of five factors that contribute to a positive learning environment: 1) comfort (creating a feeling of safety, accommodating errors, giving students the freedom of expressing themselves without constraints, creating the feeling of belonging to peer group); 2) clarity (providing clear instructions, breaking down material to smaller chunks to maintain the feeling of accomplishment, however small); 3) respect (mutual respect between students and the teacher); 4) relationships (particularly caring relationships between the teacher and individual students, teacher attending each student individually); 5) responsibility (giving students a degree of control over decisions concerning their learning).

Indeed, if the mastery of information or skill to be learned leads to success and if positive emotion is one of the cornerstones of learning, it would be reasonable to take this approach into account in higher education as well (Chafouleas \& Bray, 2004). Carruthers and Hood (2005) point out that in future, more and more attention will be paid on creating optimal social settings instead of fixing such conditions that we want to avoid.

\section{Methodology}

Using the descriptive research design paradigm, this article shall present an illustration of the factors that comprises the university students' study paths. Our findings are based on practical teaching and supervising experience at the university level as well as other relevant research and literature. Thus, the findings of this article and the final interpretation are merely the result of theoretical contemplation and review.

\section{Results: Four Core Factors that Direct Students' Study Process}

Success in studies is a sum of many factors. In Figure 1, we present four core factors that direct students' study process: a student, university community, study plan, and university teacher. Although they do not explain a successful study path and learning alone, their development and meaning should be paid more and more attention to at universities. Next, we will introduce all these factors in detail.

\subsection{The Student}

Students' study paths vary greatly depending on their starting points and experiences they get during their education. Abilities and habits refer to a student's learning history and experiences that can strengthen either one's knowledge and self-efficacy or insufficiency. Through these experiences, a student have built a positive or negative conception of himself/herself as a learner and this conception is either strengthened or dashed at the university. Furthermore, it has been shown that students' abilities to use teaching technology and ICT affect their success in studies (Lindblom-Ylänne \& Pihlajamäki, 2003). 


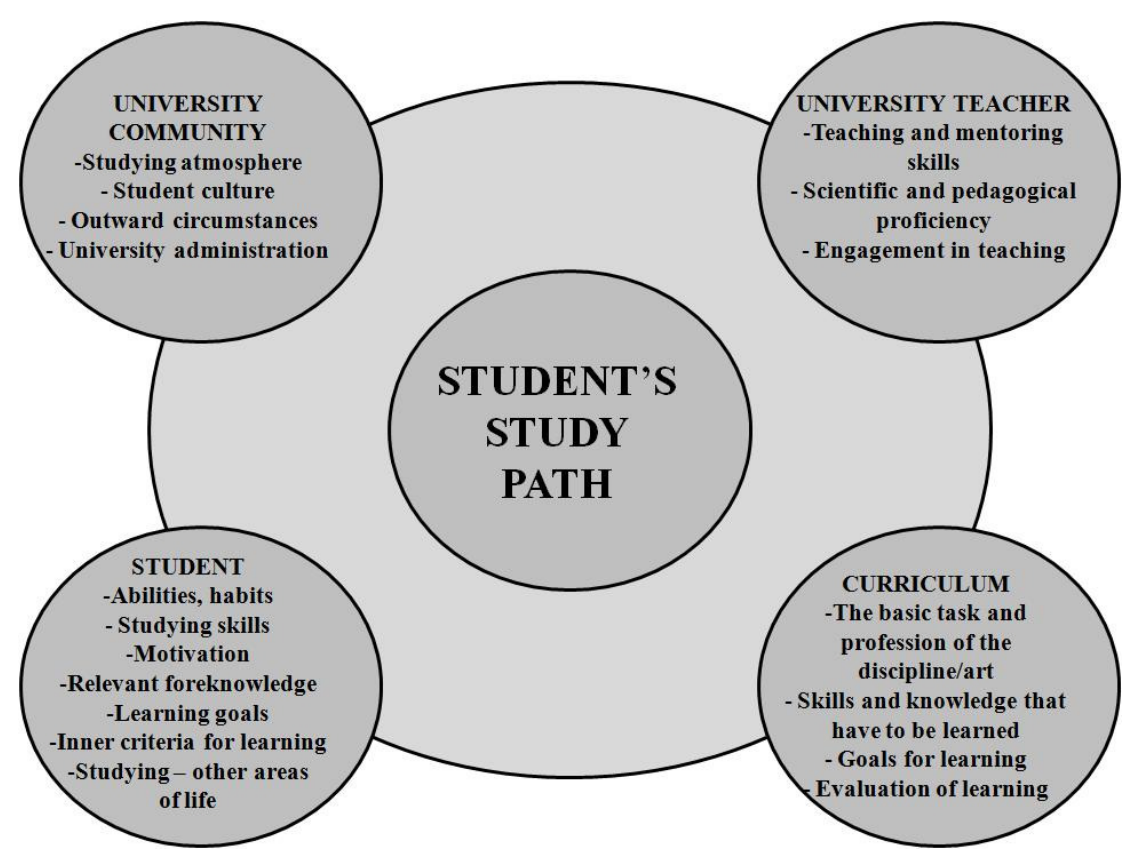

Figure 1. Study path and its core factors (Designed by Määttä)

Due to previous studies, students' studying skills can be surface or rote-learning oriented or in-depth oriented. Likewise, writing and reading skills as well as attitudes toward studying can inspire learning or cause uncertainty. Students' skills to regulate their learning and their capability to take responsible on studying may vary greatly (see e.g. Biggs, 1987).

Students' motivation reflects in their way of seizing studies and persistence (Allen, 1999; Mäkinen, 2000). Strong intrinsic motivation makes survival from problematic and challenging phases easier because then learning and acquiring knowledge and skills are considered rewarding as such (see also Ryan \& Deci, 2000). Certainly, outer rewards matter too. Receiving positive and encouraging feedback on one's own progress is important as it improves one's receptiveness to new learning experiences and tolerance of failures. On the other hand, the perceived feeling of insufficiency, poor performance level, teachers' inadequate guidance or disinterest and previous failure experiences decrease motivation. Through them, insecurity, shyness, fears, or tension may lead to extreme difficulties in going to have an exam, hold a presentation, address the study group, or express an opinion in a guidance situation.

Furthermore, relevant foreknowledge in the form of expectations and perceptions about university studies, academic field, and prospects after graduation affect the starting of studying. In order to progress in studies, one should realize one's short and long-term learning needs and goals and plan one's use of time both for the whole education and by semesters. Studying should also be in balance with other areas of life: interesting hobbies, good human relationships and family life, versatile and relaxing leisure time without homesickness act as a good counterbalance to studying (e.g. Lowe \& Gayle, 2007).

\subsection{The University Community}

Many characteristics of university community either enhance or hinder students' smooth progress on their study process. Studying atmosphere can vary from open and vivid dealings between students and teachers and other personnel to distant, minimal, and formal relationships between the above-mentioned groups. Indeed, the meaning of informal student-faculty contacts and learning outcomes has been noted already three decades ago (see Pascarella, 1980). Also students' mutual relationships and the overall studying atmosphere are important; the atmosphere can be competitive or collaborative, hurried or engrossing, flexible or engaging, school-like and 
How to enhance the smoothness of university students' study path?

performance-oriented or individualistic where students are noticed as their own personalities. Furthermore, faculties and disciplines differ from each other when it comes to students' opportunities to affect the curriculum planning and organization of teaching: the atmosphere can vary from authoritative to democratic.

Even the same discipline can involve various student cultures which can be, for example, profession-oriented, scientific-academic, philosophical-ideological, and/or co-operative culture. Students' interaction may be tribal, active, or passive. Social support and shared experiences are important not only to students' wellbeing but also to their progress in studies (see also Renn \& Arnold, 2003; Renchler, 1992).

The outward circumstances cover studying facilities and their location, the number of teachers in proportion to the number of students, social, economic, and health services, library services (the availability of books, opening times), ICT facilities and their sufficiency, the length of studying days, the accumulation of lectures versus even division by weekdays and time. It is a known fact (e.g. Greenwald, Hedges, \& Laine, 1996) that a broad range of resources are positively related to student outcome (see also Atjonen, 2007).

Student-specific outward circumstances comprise a student's financial situation, residence, and personal relationships. The reformation of traditional family life is having profound effects on society, children and the schools, and on institutions of higher education: it affects on students' background as they but also on their personal situations (Keller, 2001).

\subsection{The Curriculum}

The curriculum provides both teachers and students with a clear goal. The curriculum answers the questions of what kinds of expertise students will have in the training program and what kinds of study entities they will study along with the study units. Five stages can be distinguished in curriculum work (see Alaoutinen et al., 2009):

$>\quad$ to define the basic task and profession of the education/discipline/art, to evaluate the need for education;

$>\quad$ to define required competencies and general goals of teaching;

$>\quad$ to define the model of curriculum;

$>\quad$ to define the goals, contents, workload, and methods for study entities and units;

$>\quad$ to determine the communication in the curriculum; and

$>\quad$ to evaluate the curriculum and the proficiency produced by it and its constant development.

The learning goals in the curriculum tell what students are expected to know after taking a certain study unit. They also direct the working and evaluation way of learning, teaching, and studying. Dimensioning a study unit is supposed to guarantee that students have enough time to digest the information taught during the study period.

The forms and proportions between obligatory and optional studies in university curricula may differ greatly (see e.g. Jakku-Sihvonen et al., 2011). However, Gardiner (1994) points out that types and breadth of courses available, specific courses in the curriculum, and degree of choice may make relatively little difference in educational outcomes, although a true-core curriculum, found in a few institutions, can be positively associated with many valued outcomes.

\subsection{The University Teacher}

The completion of an academic degree is, ultimately, the student's responsibility because even the most skillful teacher cannot learn on students' behalf. Yet, teaching skills, teachers' ability to be in an appreciating 
Määttä, K. \& Uusiautti, S.

interaction with students and to guide students are a salient impetus - or pitfall - in university education. In addition to learning skills, also teaching skills can be practiced and developed. Today's good university teacher bears the responsibility both for the discipline he/she represents and his/her students and their success at studies.

The quality of university teaching can be evaluated with many criteria: substance knowledge, breadth, topicality, theory versus practice-orientation, necessity versus redundancy, interesting versus platitudeness, difficulty versus intelligibility, fragmentariness or structure, hastiness or concentration. Ideal university teaching is based on research and thus it can be research-based, evidence-based, or research-oriented (Lahtinen \& Toom, 2009). Shulman (1987) distinguishes two areas of knowledge: content knowledge which pedagogical knowledge should merge with.

Määttä (2011) has divided the resources of a good supervisor into four dimensions: Knowledge, proficiency, will, and actions constitute the four fundamental features of supervision and the corresponding characteristics explain the smoothness of a PhD student's doctoral process as well. The length of the square's sides varies with the supervision situation. Nor does the area remain the same. A supervisor can emphasize different features depending on his/her own style as well as on a doctoral students' work habits and supervision needs. Supervision is not likely to succeed if one of the following resources is completely missing:

A. Will: A supervisor's commitment to supervision,

B. Knowledge: substance knowledge and/or the mastery and ability to comprehend the overall structure,

C. Actions: Ensuring that the contents meet the scientific quality requirements, and

D. Proficiency: positive and supportive supervision methods and personality.

Lahtinen and Toom (2009) have characterized a good university teacher with the following characteristics: Good teachers

$>$ are good learners,

$>$ are enthusiastic about the things they teach and want to share their enthusiasm with students,

$>$ understand the wider connections of the things they teach and are able to adopt their teaching to meet students' needs,

$>$ encourage students to learning that enhances understanding, critical thinking, and problem-solving skills,

$>$ encourage students to expand and mold their knowledge,

$>$ set clear goals,

$>$ use appropriate and relevant evaluation methods,

$>$ give students well-grounded feedback, and

$>$ respect students and are interested in both students' professional and personal growth (see also Määttä \& Uusiautti, 2011a; 2011b).

\section{Discussions: A Good University Teacher acts as a Mentor}

Students' need for support varies and passive students may be totally ignored or forgotten. Active and motivated students are easy to guide but how to get the most passive one become inspired (see McCombs \& Pope, 1994)? These students need more than just the information that the teacher or counselor is available. It has been noted (Lindblom-Ylänne, 2004) that those students who progress in the fastest manner in their studies and 
How to enhance the smoothness of university students' study path?

who want to have even better success benefit also the most from guidance. Those ones who have most problems benefit the least from guidance - or at least the most slowly. They do not recognize their problems nor are they able to see the value of advice. Their belief in themselves, self-efficacy (Schunk \& Pajares, 2005; Maddux, 2002), is low and they need plenty of guidance and patience.

In modern world, student groups are more heterogeneous than ever. Therefore, it is essential that students learn how to live and work effectively with others who differ from themselves (e.g. Zhao, Kuh, \& Carini, 2005) and that placed a new challenge for the implementation of education (Watts \& Smolicz, 1997). Cruce, Wolniak, Seifert, and Pascarella's (2006) research provided evidence that good practices in education have a compensatory effect for those students who enter university below the average on a particular measure of cognitive ability or orientation to learning. Concerning especially the latter, students' backgrounds have indeed changed as nowadays there are less and less those who come from a so-called traditional family (San Antonio, 2008). This, in fact, is an important issues because students' abilities to stay engaged in school can be affected by students' home responsibilities, lack of family resources, and peer-group tensions related to social class hierarchies. Low-income students in particular benefit from having a meaningful relationship with at least one school staff member who knows their interests, skills, and struggles (see San Antonio, 2008).

According to Finnish Student Health Service (Kunttu \& Huttunen, 2008), only a little over half of university students feel like belonging to some study group. About a third of them do not feel like belonging to any group. In Susanna Lähteenoja's (2010) research, over half of 270 new university students who participated in the research had never discussed scientific questions, their studies, difficulties or future plans with teachers. Haapaniemi, Voutilainen, and Ikäheimonen (2001) have studied students' opinions on good mentoring. According to the results, good mentoring consists of the factors that are presented in Table 1.

\section{Table 1}

The features of good student counseling

\begin{tabular}{|c|c|}
\hline Items & Attributes \\
\hline \multirow[t]{5}{*}{ Professionalism } & problems are solved and studies progress \\
\hline & supervision situations are well-prepared \\
\hline & guidance is concrete \\
\hline & guidance is actions, not just talking \\
\hline & focus is on relevant issues \\
\hline \multirow[t]{4}{*}{ Supports Autonomous Studying } & gives support but does not pressure \\
\hline & shows direction, sets limits, and gives space \\
\hline & excessive guidance diminishes initiative \\
\hline & inspires \\
\hline \multirow[t]{2}{*}{ Covers the Whole Study Time } & regular \\
\hline & continuous \\
\hline Individualism & $\begin{array}{l}\text { pays attention to various goals and individual needs for supervision } \\
\text { notices opportunities }\end{array}$ \\
\hline \multirow[t]{3}{*}{ Interaction } & honesty, notices the student \\
\hline & teacher is interested in the students, empathetic \\
\hline & enough time should be reserved \\
\hline \multirow[t]{2}{*}{ Sufficient and Clear Communication } & questions are answered \\
\hline & one cannot (do not know how to) ask everything \\
\hline
\end{tabular}

Source. Haapaniemi, Voutilainen, \& Ikäheimonen, 2001 (translated by S. Uusiautti) 
Määttä, K. \& Uusiautti, S.

The foci of teacher mentoring can be illustrated through three-dimensional development and growth that take place during university studies (see Figure 2). Namely, studying at university presents to the time of growth as a student and as a member of a study community - both in professional and personal sense.

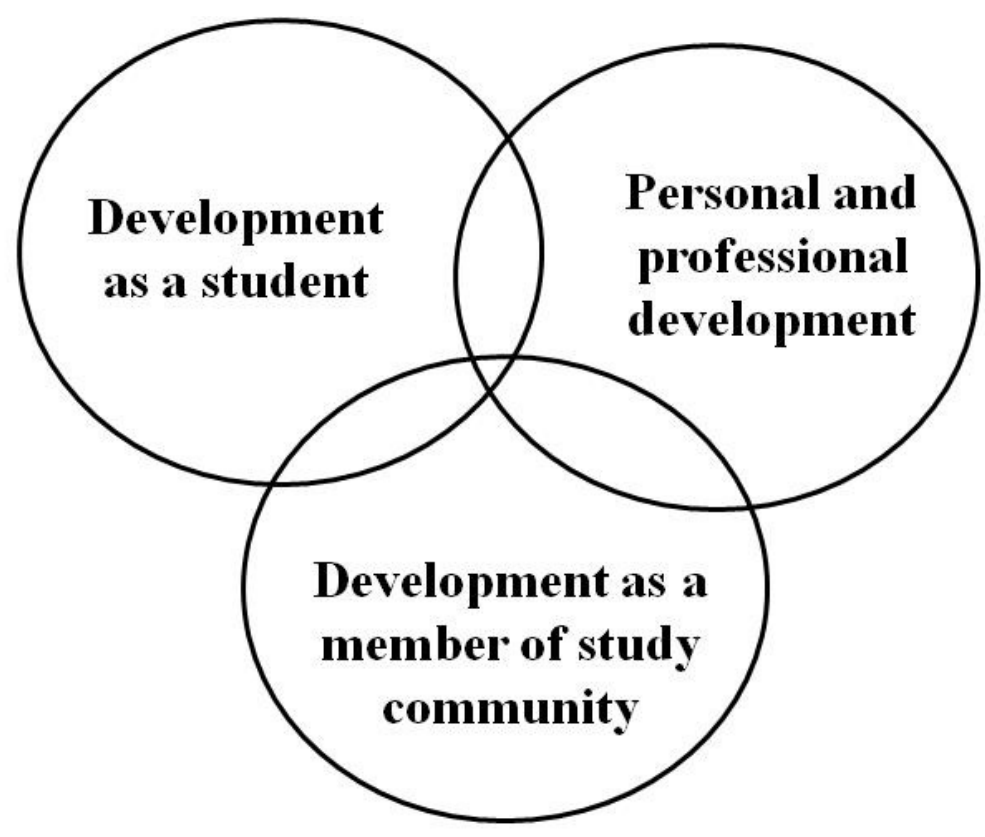

Figure 2. Three dimensions of a student's development during university education (Designed by Määttä)

As the statistics referred in introduction proved, studying at tertiary level appears as challenging. Therefore, the role of a teacher as a mentor has become more and more important and versatile. In order to enhance students' development, a good university teacher is able as a mentor to create or help students to compose their personal study plan and see the connections with working life. Furthermore, students' life-long learning and development should be taken into consideration. How to support their enthusiasm for learning new things and perceiving challenges as opportunities to develop (see e.g. Määttä, 2011a; Uusiautti \& Määttä, 2010).

Baldwin and Williams (1988) have presented a list of five factors contributing to students' life-long development:

1. climate (creating safe learning environment and reassuring atmosphere);

2. support (creating the atmosphere of encouragement and providing opportunities for mutual learning);

3. stepping (involves grading the course content so that completion of one step leads to another, more advanced stage);

4. challenge (guiding learners into new, unknown areas and exposing them to risk);

5. reflection (evaluating course activities and relating them to the reality outside course boundaries).

It seems important that teachers paid attention to the above-mentioned issues when mentoring students.

Flynn and Vredevoogd (2010) suggest that we need to seek out the change: universities and colleges have to be more flexible, more thoughtful, and more open to student decision making. By engaging students in the above-mentioned way, they are more likely to adopt institutional mission as this has shown to have a relationship 
How to enhance the smoothness of university students' study path?

between institutional mission and the five benchmarks of effective educational practice. According to Kezar and Kinzie (2006, p. 169), emphasizing empowerment, service, leadership, and activism as part of engagement is an important strategy because effective educational institutions that excel in student engagement are sensitive to their mission and use it to enhance student engagement strategies. Not only ideal outward circumstances, but the sense of mission and personal touch as well as perceived care by the university community may be the key when making students' study paths meaningful, engaging, and smoother.

\section{Conclusion}

In this article, we wanted to discuss what good university studying is and how teachers are able to make students progress with their study paths smoother. We argued that teachers should act as mentors who further students' engagement in studying. When pursuing making students' study paths more effective, it is important to invest energy in planning future studies and student counseling already at the initial phase of studies (e.g. Cruce et al., 2006). Planning and guidance should not, however, mean that the young students were pushed to make decisions that would close some doors for good too early. Moreover it is worth remembering that no one prolongs studies or their commencement in order to drain the society's reserves as much as possible.

Thus, the happiest thing would be that every student could progress in their studies smoothly and in a degree-oriented manner parallel to their own dreams and goals simultaneously amassing their talents and resources. At its best, it would fulfill those expectations that are set at universities for implementing basic education as well.

\section{References:}

Alaoutinen, S., Bruce, T., Kuisma, M., Laihanen, E., Nurkka, A., Riekko, K., Tervonen, A., Virkki-Hatakka, T., Kotivirta, S., \& Muukkonen, J. (2009). LUT:n opettajan laatuopas [Quality Manual for Teachers in Lappeenranta University of Technology]. Lappeenranta: Lappeenranta University of Technology. Retrieved from http://www.lut.fi/fi/lut/introduction/quality/qualitybook/Documents/Opettajan_Laatuopas_B5_final.pdf

Allen, D. (1999). Desire to finish college: En empirical link between motivation and persistence. Research in Higher Education, 40(4), 461-485. doi:10.1023/A:1018740226006 <http://dx.doi.org/10.1023/A:1018740226006>

Atjonen, P. (2007). Educational technology and technology education for a better private and public life Principles and practices from the Finnish viewpoint. In R. Jakku-Sihvonen \& H. Niemi (Eds.), Education as a Societal Contributor (pp. 91-110). Frankfurt: Peter Lang.

Baldwin, J., \& Williams, H. (1988). Active learning: A trainer's guide. UK: Blackwell Education.

Baltes, P. B., \& Freund, A. M. (2006). Ihmisen vahvuudet ja viisaus [The human strengths and wisdom]. In L. G. Aspinwall \& U. M. Staudinger (Eds.), Ihmisen vahvuuksien psykologia [The psychology of human strengths] (pp. 34-46). Helsinki: Edita.

Biggs, J. B. (1987). Student approaches to learning and studying. Hawthorn: Australian Council for Educational Research. Retrieved from http://eric.ed.gov/PDFS/ED308201.pdf

Carruthers, C., \& Hood, C. D. (2005). The power of positive psychology. Parks \& Recreation, Oct2005, 30-37.

Carver, C. S., \& Scheier, M. F. (2002). Optimism. In C. R. Snyder \& S. J. Lopez (Eds.), Handbook of positive psychology (pp. 231-243). Oxford: Oxford University Press.

Chafouleas, S. M., \& Bray, M. A. (2004). Engagement, disengagement, coping, and catastrophe. In A. J. Elliot \& C. S. Dweck (Eds.), Handbook of Competence and Motivation (pp. 527-547). New York, NY: The Guilford Press.

Covey, S. R. (2004). Seven habits of highly effective people. UK: Simon \& Schuster.

Cruce, T., Wolniak, G. C., Seifert, T. A., \& Pascarella, E. T. (2006). Impacts of good practices on cognitive development, learning orientations, and graduate degree plans during the first year of college. Journal of College Student Development, 47(4), 365-383. doi:10.1353/csd.2006.0042 
Määttä, K. \& Uusiautti, S.

$<$ http://dx.doi.org/10.1353/csd.2006.0042>

Deci, E. L., Vallerand, R. J., Pelletier, L. G., \& Ryan, R. M. (1991). Motivation and Education. The seld-determination perspective. Educational Psychologist, 26(3-4), 325-346. doi:10.1207/s15326985ep2603\&4_6 <http://dx.doi.org/10.1207/s15326985ep2603\&4_6>

Finnish Ministry of Education and Culture. (2010). Ei paikoillanne, vaan valmiit, hep! [Not Steady, but Ready, $G O$ !]. Helsinki: Ministry of Education and Culture. Retrieved from: http://www.minedu.fi/OPM/Julkaisut/2010/opintojen_nopeuttaminen.html?lang=fi\&extra_locale=fi

Flethcer, A. (2005). Meaningful student involvement. Guide to students as partners in school change (2nd ed.) Olympia, WA: The Free Child Project. Retrieved from http://www.soundout.org/MSIGuide.pdf

Flynn, W. J., \& Vredevoogd, J. (2010). The future of learning: 12 Views on emerging trends in higher education. Planning for Higher Education, 38(2), 5-10.

Greenwald, R., Hedges, L. V., \& Laine, R. D. (1996). The effect of school resources on student achievement. Review of Educational Research, 66(3), 361-396.

Haapaniemi, T., Voutilainen, U., \& Ikäheimonen K. (2001). Millä eväillä ohjauskokeiluihin? [With what provisions to mentoring experiments?] In U. Voutilainen \& T. Haapaniemi (Eds.), Ohjaus - opiskelun voimavara [Mentoring - A resource for studying] (pp. 97-112). Kuopio: University of Kuopio. Retrieved from http://www.uku.fi/kirjasto/julkaisutoiminta/isbn951-781-126-8.pdf

Jakku-Sihvonen, R., Tissari, V., Ots, A., \& Uusiautti, S. (2011, accepted). Teacher education curricula after the Bologna Process - A comparative analysis of written curricula in Finland and Estonia. Scandinavian Journal of Education.

Keller, G. (2001). The new demographics of higher education. The Review of Higher Education, 24(3), 219-235. doi:10.1353/rhe.2001.0004<http://dx.doi.org/10.1353/rhe.2001.0004>

Kezar, A. J., \& Kinzie, J. L. (2006). Examining the ways institutions create student engagement: The role of mission. Journal of College Student Development, 47(2), 149-172. doi:10.1353/csd.2006.0018 $<$ http://dx.doi.org/10.1353/csd.2006.0018>

Knowles, M. (1975). Self-directed learning. New York, NY: Association Press.

Kuh, G. (2003). What we're students. Benchmarks for effective educational practices. Change, March/April, 24-32. doi:10.1080/00091380309604090 <http://dx.doi.org/10.1080/00091380309604090>

Kuh, G. D., Cruce, T. M., Shoup, R., Kinzie, J., \& Gonyes, R. M. (2008). Unmasking the effects of student engagement on first-year college grades and persistence. The Journal of Higher Education, 79(5), 540-563. doi:10.1353/jhe.0.0019 <http://dx.doi.org/10.1353/jhe.0.0019>

Lahtinen, A. M., \& Toom, A. (2009). Yliopisto-opetuksen käytäntö ja yliopisto-opettajan ammatillinen kehittyminen [The practice of university teaching and university teachers' professional development]. In S. Lindblom-Ylänne \& A. Nevgi (Eds.), Yliopisto-opettajan käsikirja [A University Teacher's Manual] (pp. 31-45). Helsinki: WSOYpro.

Leppilampi, A. \& Piekkari, U. (2009). Opitaan yhdessä-Aikuiskoulutusta yhteistoiminnallisesti [Let's learn together-Adult education in a collaborative manner]. Lahti: Asko Leppilampi Oy.

Lindblom-Ylänne, S. (2004). Raising students' awareness of their approaches to study. Innovations in Education and Teaching International, 41, 405-422. doi:10.1080/1470329042000277002 $<$ http://dx.doi.org/10.1080/1470329042000277002>

Lindblom-Ylänne, S., \& Pihlajamäki, H. (2003). Adjusting law teaching to social change: An historical perspective to legal education. Retfaerd, 101, 5-19.

Locke, E. A. (2002). Setting goals for life and happiness. In C. R. Snyder \& S. J. Lopez (Eds.), Handbook of positive psychology (pp. 299-312). Oxford: Oxford University Press.

Lowe, J., \& Gayle, V. (2007). Exploring the work/life/study balance: the experience of higher education students in a Scottish further education college. Journal of Further and Higher Education, 31(3), 225-238. doi:10.1080/03098770701424942 <http://dx.doi.org/10.1080/03098770701424942>

Lähteenoja, S. (2010). Uusien opiskelijoiden integroituminen yliopistoon - Sosiaalipsykologinen näkökulma [New Students' Integration to the Universtity - A Social-Psychological Perspective]. Helsinki: University of Helsinki. Retrieved from http://urn.fi/URN:ISBN:978-952-10-6086-1 
How to enhance the smoothness of university students' study path?

Maddux, J. E. (2002). Self-efficacy. The power of believing you can. In C. R. Snyder \& S. J. Lopez (Eds.), Handbook of positive psychology (pp. 277-287). Oxford: Oxford University Press.

Magnusson, D., \& Mahoney, J. L. (2006). Holistinen lähestymistapa myönteisen kehityksen tutkimuksessa [Holistic approach on research of positive development]. In L. G. Aspinwall \& U. M. Staudinger (Eds.), Ihmisen vahvuuksien psykologia [The psychology of human strengths] (pp. 232-250). Helsinki: Edita.

McCombs, B. L., \& Pope, J. E. (1994). Motivating Hard to Reach Students. Washington, DC: APA. $<$ http://dx.doi.org/10.1037/10151-000>

Ministry of Education and Culture. (2010). Student survey 2010 - University students' subsistence and studying. Helsinki: Ministry of Education and Culture. Retrieved from http://www.minedu.fi/OPM/Julkaisut/2010/Opiskelijatutkimus_2010.html

Mäkinen, M. (2000). Mikä minusta tulee “isona”? Yliopisto-opiskelijan ammattikuvan kehittyminen [What will I become "when big"? The development of a university student's professional image]. In P. Tynjälä, J. Välimaa, \& M. Murtonen (Eds.), Korkeakoulutus, oppimine ja työelämä [Higher education, learning, and working life] (pp. 77-90). Jyväskylä: PS-Kustannus.

Määttä, K. (2011a). The dissertation process described by doctoral students in Finland. E-International Journal of Educational Research, 2(1), 66-80.

Määttä, K. (2011b, in press). The pedagogy of supervising doctoral theses. In K. Määttä (Ed.), Obsessed with the Doctoral theses: What is the supervision and support the doctorates tell to need in the phases of dissertation process? (pp. 143-160). Rotterdam: Sense.

Määttä, K., \& Uusiautti, S. (2011a, accepted). Pedagogical love and good teacherhood. In Education.

Määttä, K., \& Uusiautti S. (2011b, accepted). Pedagogical authority and pedagogical love - connected or incompatible. International Journal of Whole Schooling.

OECD. (2010). Education at a Glance. Retrieved from http://www.oecd.org/dataoecd/45/39/45926093.pdf

Pascarella, E. T. (1980). Student-faculty informal contact and college outcomes. Review of Educational Research, 50, 545-595. doi:10.3102/00346543050004545 <http://dx.doi.org/10.3102/00346543050004545>

Pintrich, P. R. (1999). The role of motivation in promoting and sustaining self-regulated learning. International Journal of Educational Research, 31(6), 459-470. doi:10.1016/S0883-0355(99)00015-4 $<$ http://dx.doi.org/10.1016/S0883-0355(99)00015-4>

Renn, K. A., \& Arnold, K. D. (2003). Reconceptualizing research on college student peer culture. Journal of Higher Education, 74(3), 261-291. doi:10.1353/jhe.2003.0025 <http://dx.doi.org/10.1353/jhe.2003.0025>

Renchler, R. (1992). Student motivation, school culture, and academic achievement. What school leaders can do. Oregon: University of Oregon. Retrieved from http://eric.uoregon.edu/pdf/trends/motivation.pdf

Ryan, R. M., \& Deci, E. L. (2000). Self-determination theory and the facilitation of intrinsic motivation, social development, and well-being. American Psychologist, 55(1), 68-78. doi:10.1037/0003-066X.55.1.68 $<$ http://dx.doi.org/10.1037/0003-066X.55.1.68>

San Antonio, D. M. (2008). Understanding students' strengths and struggles. Educational Leadership, Apr/2008, 74-79.

Schoon, I., Salmela-Aro, K., Silbereisen, R. K., Eccles, J., Schneider, B., Trautwein, U., \& Bergman, L. (2010). Pathways to adulthood: Towards a unifying framework. Retrieved from http://www.pathwaystoadulthood.org/docs/unifyingframeworkdoc.pdf

Schunk, D. H., \& Pajares, F. (2005). Competence perceptions and academic functioning. In A. J. Elliot \& C. S. Dweck (Eds.), Handbook of Competence and Motivation (pp. 85-104). New York, NY: The Guilford Press.

Shulman, L. S. (1987). Knowledge and teaching: Foundations of the new reform. Harvard Educational Review, 57 (1), 1-22.

Strong, R., Silver, H., \& Robinson, A. (1995). What do students want (and what really motivates them)? Educational Leadership, Sep/1995, 25.

Sundvall-Huhtinen, A. (2007). Tulevaisuusorientaation huomioiminen nuoren ohjauksessa [Noticing future 
Määttä, K. \& Uusiautti, S.

orientation when guiding the young]. In J. Helander (Ed.), Reunamerkintöjä ohjaukseen II - avauksia ja aavistuksia opinto-ohjauksen nykyisyydestä ja tulevaisuudesta [Notes about Student Counseling II Openings and Clues about the Present State and Future of Student Counseling] (pp. 13-22).

Hämeenlinna: Häme University of Applied Sciences.

Theilheimer, R. (1991). Involving students in their own learning. Clearing House, 65(2), 123-126.

Uusiautti, S., \& Määttä, K. (2011, accepted). The process of becoming a top worker. International Education Studies.

Watts, R. J., \& Smolicz, J. J. (1997). Cultural democracy and ethnic pluralism. Multicultural and multilingual policies in education. Frankfurt: Peter Lang.

Zhao, C. M., \& Kuh, G. D. (2004). Adding value: learning communities and student engagement. Research in Higher Education, 45(2), 115-138. doi:10.1023/B:RIHE.0000015692.88534.de $<$ http://dx.doi.org/10.1023/B:RIHE.0000015692.88534.de $>$

Zhao, C. M., Kuh, G. D., \& Carini, R. M. (2005). A comparison of international student and American student engagement in effective educational practices. The Journal of Higher Education, 76(2), 209-231. doi:10.1353/jhe.2005.0018 <http://dx.doi.org/10.1353/jhe.2005.0018> 